\title{
INFLUENCE OF DOUBLE CROPPING ON GROWTH AND YIELD OF DRY BEANS WITH COLORED PLASTIC MULCHES
}

\author{
Luis Ibarra-Jiménez ${ }^{*}$, Luis Alonso Valdez-Aguilar ${ }^{2}$, Antonio Cárdenas-Flores ${ }^{1}$, Hugo Lira-Saldivar ${ }^{1}$, \\ Javier Lozano-del Río ${ }^{3}$, and Carlos Lozano Cavazos ${ }^{3}$
}

\begin{abstract}
There are numerous studies of the use of plastic mulches in vegetable production, but there is little documentation of their use with dry beans (Phaseolus vulgaris L.) in single and double cropping. The objective of this study was to grow dry beans over two consecutive growing seasons using the same plastic mulch of different colors and examine the influence of soil temperature on growth and yield. The experiment was conducted in Saltillo, Coahuila, Mexico, in the spring and summer of 2008. The treatments included four colored plastic mulches: white-on-black, black, silver-on-black, aluminum-on-black, and bare soil as a control. The experimental design was a randomized complete block with four replicates. The percentage of photosynthetically active radiation (PAR) reflected from the plastic tended to be highest with the white-on-black mulch and lowest with the black mulch. Mean soil temperature under the plastic mulch decreased with the increasing percentage of reflected PAR. Mean soil temperature exhibited a relationship of $98 \%$ and $99 \%$ to yield in the first and second growing season, respectively. Photosynthetically active radiation had a relationship of $98 \%$ and $86 \%$ to yield in the first and second growing season, respectively. The effect of the colored plastic mulch on yield was significant $(\mathrm{p} \leq 0.05)$ in the first growing season but not in the second, where plastic mulch and bare soil treatments had similar yields, indicating that plastic mulches do not always increase yield.
\end{abstract}

Key words: Phaseolus vulgaris, soil temperature, photosynthesis, PAR, plasticulture.

$P_{d}$ lastic mulching provides the opportunity to obtain double crops by using the same production system in two consecutive growing seasons. There is a possibility of increasing the cost-effectiveness of plastic mulching while reducing the negative impact on the environment by using the same plastic film for double cropping (Waterer et al., 2007). Double cropping reduces the cost of plastic mulch and drip irrigation tapes and decreases plastic residues in the field (Hanna, 2000a; 2000b; Ngouajio and Ernest, 2005). In regions where a long growing season is possible, fall crops can be planted in the mulched plot once the spring crop has been removed (Hanna, 2000a). In regions with a short growing season, the second crop is planted in the spring of the following year, leaving the plastic film exposed for longer than $1 \mathrm{yr}$ to obtain a second harvest. The success of the second crop depends on maintaining the physical, optical, and thermal properties of the polyethylene in good condition for the second

${ }^{1}$ Centro de Investigación en Química Aplicada, Departamento de Plásticos en la Agricultura, Blvd. Enrique Reyna 140, Saltillo, México. *Corresponding author (libarra@ciqa.mx).

${ }^{2}$ Universidad Autónoma Agraria Antonio Narro, Departamento de Horticultura, Buenavista, Saltillo, México.

${ }^{3}$ Universidad Autónoma Agraria Antonio Narro, Departamento de Fitomejoramiento, Buenavista, Saltillo, México.

Received: 31 January 2012.

Accepted: 18 July 2012. season (Ngouajio and Ernest, 2005; Waterer et al., 2007).

Double cropping in the same year (Hanna, 2000a; $2000 b$ ) or different crops in different years (Ngouajio and Ernest, 2005) has been well documented. However, it is possible that the yield in the second season may be lower as consequence of the lost of properties of the plastic (polyethylene) caused by the prolonged exposition to radiation.

The common dry bean (Phaseolus vulgaris L.) is the world's most important legume for direct human consumption, especially in Latin America and in East and southern Africa. Twelve million metric tons are harvested annually worldwide, of which about 8 million tons are from Latin America and Africa. In Mexico, 1.07 million tons was produced in recent years (FAO, 2010).

Plastic mulching has been developed mainly for vegetable crops (Ibarra Jiménez y Rodríguez Piña, 1997; Lamont, 2005; Díaz-Pérez, 2010) and therefore there is very little information as to the effects of this technique on growth and yield in dry bean. A previous investigation in which dry bean was seeded on four different dates and mulched with a black plastic film indicated that this species responds positively by increasing yield, regardless of seeding dates. However, clear plastic films had a negative effect in three out of the four dates as seedlings collapsed due to excessive temperature stress, while plants mulched with a black plastic film exhibited 
reduced yield when seeding was conducted late in the season due to an excessive accumulation of heat in the soil (Ibarra Jiménez y Rodríguez Piña, 1997). Some farmers in northern Mexico use a production system in which plastic mulch and drip irrigation tape are used for double cropping of melon (melon after melon), with the potential benefit of obtaining higher profits.

The objective of the present study was to evaluate the possibility of obtaining two consecutive crops of dry beans on the same plastic mulch of different colors, and to examine the influence of soil temperature on growth and yield.

\section{MATERIALS AND METHODS}

Field studies were conducted at the Centro de Investigación en Química Aplicada, Saltillo, Coahuila, Mexico during 2008. Soil pH in the experimental site was 7.3 and the soil had a clayey texture (clay $47 \%$, silt $32 \%$, and sand $21 \%$ ).

The experimental unit for the two growing seasons consisted of individual beds ( $0.6 \mathrm{~m}$ wide, $7 \mathrm{~m}$ long) spaced $1.8 \mathrm{~m}$ apart. Beds were mulched with plastic films of four colors: white-on-black, black, silver-on-black, aluminumon-black, and bare soil as control. All the polyethylene plastic mulches used were $0.03 \mathrm{~mm}$ thick and $1.2 \mathrm{~m}$ wide (Pliant, Chesterbrook, Pennsylvania, USA).

Throughout each growing season (approximately 60 d), the soil was fertilized through the irrigation system to a total of $\left(\mathrm{kg} \mathrm{ha}^{-1}\right) 80 \mathrm{~N}, 40 \mathrm{P}, 0 \mathrm{~K}$, which is a rate similar to that used by bean farmers in different parts of Mexico. Only $27 \mathrm{~kg} \mathrm{~N} \mathrm{ha}^{-1}$ was applied to the second crop, with no $\mathrm{P}$ or $\mathrm{K}$ because it has been proven that with double cropping the quantity of fertilizers can be reduced in the second season (Mayfield et al., 2002). Drip irrigation tape with emitters spaced $0.305 \mathrm{~m}$ apart was placed on the soil surface $5 \mathrm{~cm}$ apart at the center of the beds. Plants in all the mulching treatments received irrigation water as necessary. Seeding of the first crop was on 30 March 2008 by placing manually seeds of cv. Peruano on a raised bed, three rows per bed, with $0.1 \mathrm{~m}$ of space between plants. Once the first crop was completed, plant residues were removed from the field and seeds of the same cultivar were seeded on 7 July 2008 in the same holes of the plastic films already installed for the first crop.

Soil temperature was measured at a depth of $0.1 \mathrm{~m}$ (midpoint between plants), using copper-constantan thermocouples $(0.6 \mathrm{~mm}$ diameter) connected to a data logger (CR23X; Campbell Scientific, Logan, Utah, USA) and a multiplexer (AM25T, Campbell Scientific). The data logger was programmed to record readings every $10 \mathrm{~s}$ and store daily values of maximum, minimum, and mean soil temperatures.

Photosynthetically active radiation (PAR) was measured with quantum sensors (Apogee Instruments, Logan, Utah, USA) for $60 \mathrm{~d}$ after seeding in both growing seasons. Reflected PAR ( $r P A R$ ) was measured by placing the quantum sensors $30 \mathrm{~cm}$ above the soil level and covering the width of the mulched bed; the sensors were placed facing the plastic mulch or the soil on non-mulched beds. The amount of PAR reflected by the mulches was expressed as a percentage of the incoming PAR. Radiation measurements were saved in the same data logger used to record the soil temperatures and at the same time interval.

The photosynthesis rate was measured using a portable photosynthesis meter (LI-6200, LI-COR, Lincoln, Nebraska, USA). Measurements were performed only on clear days between 11:00 and 13:00 h on the fourth youngest fully expanded leaf of three plants randomly selected in each plot. Dry plant biomass was determined on four sampling dates during the growing season from three plants for each experimental unit. Both crops were harvested at approximately about 80 das. Grain yield was measured as total yield per plot and transformed to $\mathrm{tha}^{-1}$.

The treatments were established in the field using a randomized complete block experimental design with four replicates. Data were analyzed using the Statistical Analysis System PROC GLM (SAS Institute, 2009) and the means were separated by LSD procedure $(P=0.05)$.

\section{RESULTS AND DISCUSSION}

\section{Soil temperature}

Averaged across plastic mulch treatments, maximum mean soil temperature was $24.3{ }^{\circ} \mathrm{C}$ during the first crop and $24.6{ }^{\circ} \mathrm{C}$ during the second, whereas minimum mean soil temperature was 20.6 and $20.4{ }^{\circ} \mathrm{C}$ for the first and second crop and soil mean soil temperature (MST) 22.6 and $22.4{ }^{\circ} \mathrm{C}$, respectively (Table 1 ). In the first crop, mulch treatments recorded a higher MST $(\mathrm{p} \leq 0.05)$ compared to that of bare soil, except for aluminum plastic mulch. In the second crop, mulch treatments in white and aluminum plastic mulches showed a MST similar to that of the control (Table 1). The differential response between

Table 1. Mean, maximum, and minimum mulched soil temperature, and reflected photosynthetically active radiation (rPAR) on dry bean crop grown with colored plastic film during spring and summer of 2008.

\begin{tabular}{lcccr}
\hline & & & \\
Film color & T media & T max & T min & rPAR \\
\cline { 2 - 3 } First crop & & & $\%$ \\
Black & $23.4 \mathrm{a}$ & $25.2 \mathrm{a}$ & $21.2 \mathrm{a}$ & 7.4 \\
Silver & $22.9 \mathrm{a}$ & $24.5 \mathrm{ab}$ & $20.9 \mathrm{a}$ & 9.4 \\
White & $22.5 \mathrm{ab}$ & $23.9 \mathrm{ab}$ & $20.7 \mathrm{ab}$ & 12.4 \\
Aluminum & $22.8 \mathrm{a}$ & $24.3 \mathrm{ab}$ & $20.9 \mathrm{a}$ & 10.6 \\
Bare soil & $21.5 \mathrm{~b}$ & $23.5 \mathrm{~b}$ & $19.3 \mathrm{~b}$ & 7.7 \\
LSD & 1.03 & 1.64 & 1.4 & $\mathrm{NA}$ \\
Second crop & & & & \\
Black & $23.0 \mathrm{a}$ & $25.9 \mathrm{a}$ & $20.8 \mathrm{ab}$ & 6.7 \\
Silver & $22.7 \mathrm{ab}$ & $25.3 \mathrm{ab}$ & $20.8 \mathrm{ab}$ & 8.6 \\
White & $22.3 \mathrm{bc}$ & $23.6 \mathrm{c}$ & $20.5 \mathrm{ab}$ & 11.8 \\
Aluminum & $22.2 \mathrm{c}$ & $24.8 \mathrm{bc}$ & $20.3 \mathrm{ab}$ & 9.7 \\
Bare soil & $22.1 \mathrm{c}$ & $23.6 \mathrm{c}$ & $19.9 \mathrm{~b}$ & 5.8 \\
LSD & 0.57 & 1.35 & 1.42 & $\mathrm{NA}$ \\
\hline
\end{tabular}

Means within each column followed by the same letter are not different at $\mathrm{p} \leq 0.05$. LSD: least significant difference. NS: non significant. NA: Not available. Data in the column came from one reaping. 
seasons in MST with white plastic may have been due to a deleterious effect on the plastic's optical properties associated with the longer exposition of the film to solar radiation by the time the second crop was established.

Colored plastic mulches significantly increased MST compared to the control; however, MST was similar during the first crop among all the plastic colors (Table 1). Results were different with the second crop because the color of the plastics significantly affected soil temperatures; MST in black plastic mulch was higher than that observed in white and aluminum films (Table 1).

A reduction in the optical properties of the plastic films by the second crop may explain the lesser difference in soil temperatures between mulched and non-mulched soils. It has been reported that white and aluminumcolored plastic mulches tend to lose short-wave radiation transmission to a greater extent than plastics of other colors. In general white mulches are more associated with lower soil temperatures than other colors (Lamont, 2005; Díaz-Pérez, 2009). The lower effect on soil temperature of the white plastic films observed in the second crop may be because they tended to loss their whiteness quickly due to the accumulation of dust and soil on the surface, turning the plastic yellow, which in turn led to a loss of optical properties after a given period (Summers et al., 1995). In contrast to the results of the present experiment, Ngouajio and Ernest (2005) reported that in a double cropping of cucumber after tomato white plastics were among those with less loss of optical properties, and that they also exhibited less heat loss duirng the second crop, which was probably because the plastic film was of better quality, allowing only $10 \%$ loss of physical properties after exposure of over a year. The severity in the loss of properties in plastics varies according to their chemical composition and the duration of exposure to the environment. Aluminum-colored plastic is considered aphid repellent since it reflects significant PAR radiation (Csizinszky et al., 1995). However, in the present study this effect was not observed because the incidence of pests was similar in all the treatments. The silverleaf whitefly (Bemisia argentifolii) was the most common pest observed in both growing seasons and was controlled by spraying conventional insecticides. A problem with aluminum mulch is that it loses shininess, thus in our study less radiation was reflected and a decrease in soil temperature was observed during the second crop. In the present study, as in others (Ham et al., 1993), black films recorded the highest MST in both growing seasons and, in accordance with Ngouajio and Ernest (2005), there was less loss of heat accumulation properties during the second crop.

\section{Vegetative growth}

In general, the plant dry weight (DW) of the second crop was lower than that of the first (Table 2). Compared to the DW of plants in bare soil, plant DW was consistently
Table 2. Dry weight at $20,30,40,50$ days after seeding (das) of dry beans plants grown with colored plastic film mulches during spring and summer of 2008 .

\begin{tabular}{llllc}
\hline & \multicolumn{4}{c}{ Plant dry weight } \\
\cline { 2 - 5 } Film color & 20 das & 30 das & 40 das & 50 das \\
\cline { 2 - 5 } First crop & & & & \\
Black & $1.01 \mathrm{a}$ & $4.06 \mathrm{ab}$ & $12.11 \mathrm{a}$ & $18.54 \mathrm{ab}$ \\
Silver & $1.07 \mathrm{ab}$ & $4.65 \mathrm{a}$ & $11.93 \mathrm{a}$ & $19.40 \mathrm{ab}$ \\
White & $1.09 \mathrm{ab}$ & $4.01 \mathrm{ab}$ & $8.67 \mathrm{ab}$ & $16.60 \mathrm{ab}$ \\
Aluminum & $1.31 \mathrm{a}$ & $4.44 \mathrm{a}$ & $10.16 \mathrm{ab}$ & $22.45 \mathrm{a}$ \\
Bare soil & $0.80 \mathrm{~b}$ & $2.72 \mathrm{~b}$ & $6.46 \mathrm{~b}$ & $12.95 \mathrm{~b}$ \\
LSD & 0.32 & 1.64 & 4.97 & 7.04 \\
Average & 1.06 & 3.98 & 9.90 & 17.99 \\
Second crop & & & & \\
Black & 1.09 & 3.34 & 8.86 & 10.36 \\
Silver & 1.02 & 3.88 & 7.32 & 10.89 \\
White & 0.99 & 2.99 & 8.59 & 11.22 \\
Aluminum & 1.03 & 3.43 & 8.00 & 11.72 \\
Bare soil & 1.08 & 2.95 & 7.88 & 11.03 \\
LSD & $\mathrm{NS}$ & $\mathrm{NS}$ & $\mathrm{NS}$ & $\mathrm{NS}$
\end{tabular}

Means within each column followed by the same letter are not different at $\mathrm{p} \leq 0.05$. LSD least significant difference. NS: non significant.

higher $(\mathrm{p} \leq 0.05)$ in the first crop when mulched with aluminum-colored plastic at 20,30, and 50 das (Table 2). Similar tendencies were observed with black, silver, and aluminum plastic mulches when plant DW was averaged across the four sampling dates (Table 3). In the second crop, plant DW was not affected by plastic mulches during the growing season and the plants grown with plastic mulch had similar behavior to the plants on bare soil (Table 2).

\section{Plant dry weight and grain yield}

In the first crop there were differences $(p \leq 0.05)$ among treatments in mean plant DW, pods per plant, 100-seed weight and grain yield (Table 3). However, this effect was not observed in the second crop since treatments with plastic mulch and bare soil had similar results in mean plant DW, seed weight and grain yield. In the second crop, there was only a difference among treatments in the

Table 3. Mean plant dry weight, pods per plant, weight of 100 seeds and yield of dry beans grown with colored plastic film mulches during spring and summer of 2008 .

\begin{tabular}{lcccc}
\hline Film color & $\begin{array}{c}\text { Mean plant } \\
\text { dry weight }\end{array}$ & $\begin{array}{c}\text { Pods per } \\
\text { plant }\end{array}$ & $\begin{array}{c}\text { Weight } \\
100 \text { seeds }\end{array}$ & Yield \\
\hline First crop & $\mathrm{g}$ & & $\mathrm{g}$ & $\mathrm{t} \mathrm{ha}^{-1}$ \\
Black & $8.93 \mathrm{ab}$ & $22.25 \mathrm{ab}$ & $41.35 \mathrm{ab}$ & $4.13 \mathrm{a}$ \\
Silver & $9.26 \mathrm{ab}$ & $23.75 \mathrm{a}$ & $40.41 \mathrm{~b}$ & $4.10 \mathrm{a}$ \\
White & $7.64 \mathrm{ab}$ & $19.75 \mathrm{ab}$ & $40.10 \mathrm{~b}$ & $3.62 \mathrm{ab}$ \\
Aluminum & $9.59 \mathrm{a}$ & $20.50 \mathrm{ab}$ & $41.03 \mathrm{~b}$ & $3.96 \mathrm{a}$ \\
Bare soil & $5.73 \mathrm{~b}$ & $17.25 \mathrm{~b}$ & $43.28 \mathrm{a}$ & $3.14 \mathrm{~b}$ \\
LSD & 1.90 & 5.20 & 2.22 & 0.95 \\
Second crop & & & & \\
Black & 5.91 & $13.25 \mathrm{ab}$ & $44.62 \mathrm{ab}$ & 2.74 \\
Silver & 5.78 & $12.25 \mathrm{ab}$ & $45.65 \mathrm{~b}$ & 2.83 \\
White & 5.95 & $14.00 \mathrm{a}$ & $45.35 \mathrm{a}$ & 2.87 \\
Aluminum & 6.04 & $12.50 \mathrm{a}$ & $46.13 \mathrm{ab}$ & 2.86 \\
Bare soil & 5.73 & $10.75 \mathrm{~b}$ & $46.05 \mathrm{ab}$ & 2.71 \\
LSD & NS & 1.0 & 1.4 & NS \\
\hline
\end{tabular}

Means within each column followed by the same letter are not different at $\mathrm{p} \leq 0.05$. LSD least significant difference. NS: non significant. 
number of seeds per pod ( $\mathrm{p} \leq 0.05$ ), although this did not result in higher grain yield. In general, early seeding in spring produce higher dry bean yields than late seeding. Similar results have been reported with dry beans (Ibarra Jiménez and Rodríguez Piña, 1997) and tomato (DíazPérez and Batal, 2002), suggesting that the use of plastic mulch is not necessarily associated with increased yields.

\section{Reflected radiation, soil temperature and yield}

Each plastic color has a different light reflection, which was confirmed in the present study since white, aluminum and silver plastic mulches reflected higher rPAR (Table 1). In both growing seasons black plastic mulch had the lowest reflected light, which was very similar to that of bare soil. In the first crop, soil temperature decreased as reflected light increased (Figure 1) and the same tendency occurred in the second crop (Figure 2).

In general, the higher reflectance of solar light with plastic mulch, the lower the absorbance (Ham et al., 1993). It has been shown for instance that the radiation reflected from plastic mulch is associated with phenols, ascorbic acid and nutrient content in carrot (Antonious and Kasperbauer, 2002), leaf area in tomato (Decoteau, 2007), and positively associated with aroma, sugar content and higher yields in strawberry (Kasperbauer, 2000; Kasperbauer et al., 2001). In the present study, during the

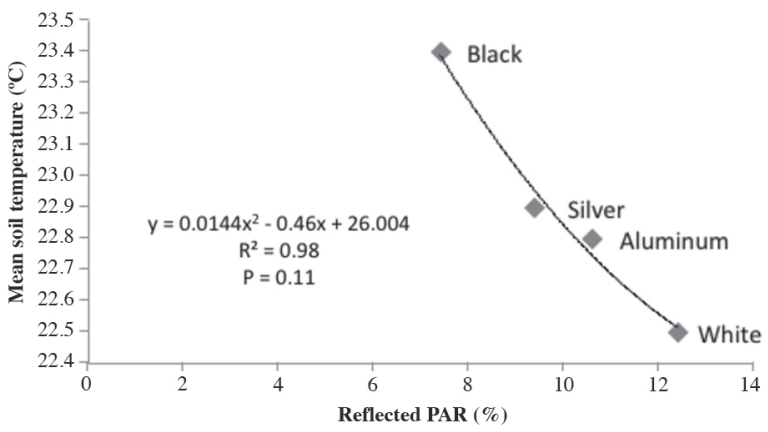

Figure 1. Relationship between mean soil temperature and photosynthetically active radiation (PAR) reflected by various colored plastic mulches during the first of two growing seasons of dry beans.

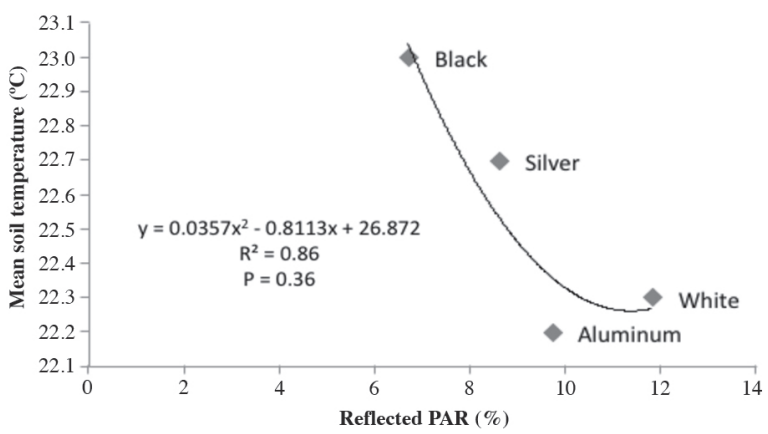

Figure 2. Relationship between mean soil temperature and photosynthetically active radiation (PAR) reflected by differentially colored plastic mulches, during the second of two growing seasons of dry beans. first crop the radiation reflected was inversely correlated $\mathrm{R}^{2}=0.99\left(\mathrm{y}=-0.0281 \mathrm{x}^{2}+0.4547 \mathrm{x}+2.3075\right)$ (Figure 3$)$, and in the second crop was positively correlated $\mathrm{R}^{2}=0.99$ $\left(y=-0.0069 x^{2}+0.1527 x+2.0255\right)$ (Figure 4) with yield Therefore, we hypothesized that rPAR did not influence yield since the different mulch colors produced opposite behaviors over the two growing seasons. It is possible that incident PAR and/or air temperature were different in the two growing seasons, which could explain this behavior. Unfortunately, we did not measure these factors so no conclusions can be made.

\section{Photosynthesis rate}

Bean plants only showed a higher photosynthesis rate when mulched in the first sampling during the first crop (Table 4). In previous studies, Ibarra-Jiménez et al. (2011) reported a significant effect of the colors of plastic mulches on net photosynthesis, especially in the initial stages of plant growth. In the present study, the photosynthesis rate was measured on the fourth youngest leaf. However, measuring the entire plant canopy could be a better estimator of the plant photosynthesis rate, allowing for a more precise interpretation. In the first crop, the influence of plastic mulch on soil temperature seems to be more important in the production of plant DM and grain yield than in photosynthesis rate. Thus, it is not worthwhile

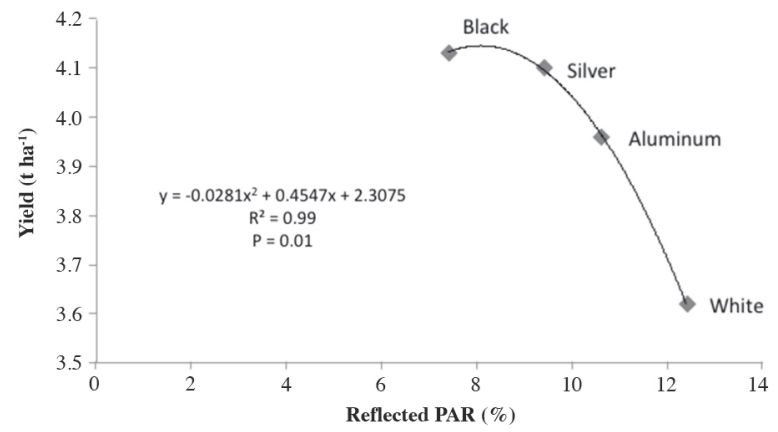

Figure 3. Relationship between photosintetically active radiation (PAR), reflected by differentially colored plastic mulches, and yield of dry beans in the first of two growing seasons.

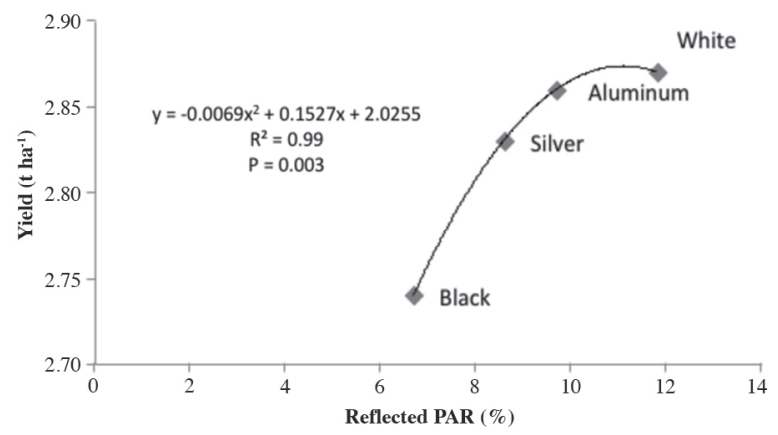

Figure 4. Relationship between photosintetically active radiation (PAR) reflected by differentially colored plastic mulches, and yield of dry beans in the second of two growing seasons. 
Table 4. Net photosynthesis rate at 20, 30, 40, and 50 days after seeding (das) of dry bean plants grown with colored plastic film mulches during spring and summer of 2008.

\begin{tabular}{lllll}
\hline & \multicolumn{4}{c}{ Net photosynthesis rate } \\
\cline { 2 - 5 } Treatment & 20 das & 30 das & 40 das & 50 das \\
\cline { 2 - 5 } First crop & & $\mu$ mol $\mathrm{CO}_{2} \mathrm{~m}^{-2} \mathrm{~s}^{-1}$ & \\
Black & $4.77 \mathrm{bc}$ & 4.86 & 6.33 & 8.54 \\
Silver & $4.06 \mathrm{ab}$ & 4.46 & 4.33 & 8.42 \\
White & $3.74 \mathrm{bc}$ & 4.71 & 4.20 & 8.47 \\
Aluminum & $5.14 \mathrm{a}$ & 4.21 & 5.44 & 8.78 \\
Bare soil & $3.53 \mathrm{c}$ & 6.39 & 7.29 & 7.98 \\
LSD & 1.05 & $\mathrm{NS}$ & $\mathrm{NS}$ & $\mathrm{NS}$ \\
Second crop & & & & \\
Black & $13.55 \mathrm{ab}$ & 8.00 & 8.27 & 7.64 \\
Silver & $13.58 \mathrm{ab}$ & 6.67 & 6.83 & 7.88 \\
White & $16.12 \mathrm{a}$ & 6.96 & 7.04 & 7.99 \\
Aluminum & $15.22 \mathrm{ab}$ & 6.69 & 8.00 & 7.41 \\
Bare soil & $12.76 \mathrm{ab}$ & 7.47 & 8.91 & 8.32 \\
LSD & 2.79 & $\mathrm{NS}$ & $\mathrm{NS}$ & $\mathrm{NS}$ \\
\hline
\end{tabular}

Means within each column followed by the same letter are not significantly different at $\mathrm{p} \leq$ 0.05 . LSD: least significant difference. NS: non significant.

to try to find differences in single-leaf photosynthesis measurements between mulched and non-mulched plants despite the difference in soil temperature. The increase in temperature was not sufficient to significantly affect the photosynthesis rate. The latter could be ascribed to environmental factors, such as PAR, air temperature, leaf temperature and ambient $\mathrm{CO}_{2}$, which were very similar in mulched and non-mulched soils.

Relationship between mean soil temperature and yield Mean soil temperature was associated with bean yield in the first crop $\left(\mathrm{y}=-1.1349 \mathrm{x}^{2}+52.667 \mathrm{x}-606.84 ; \mathrm{R}^{2}\right.$ $=0.98)$ (Figure 5) and second crop $\left(\mathrm{y}=-0.3047 \mathrm{x}^{2}+\right.$ $13.622 x-149.35 ; R^{2}=0.99$ ) (Figure 6). In general, in the first crop, yield increased as mean soil temperature increased, whereas in the second crop a temperature increase was associated with decreased yield. According to the estimated models, the optimum soil temperature for maximum bean yield was about $23^{\circ} \mathrm{C}$. It was not possible to obtain optimum soil temperature value for dry bean due to the lack of data, therefore it is not possible to determine if yield would have increased or decreased beyond what it did with the mean soil temperatures obtained in this study,

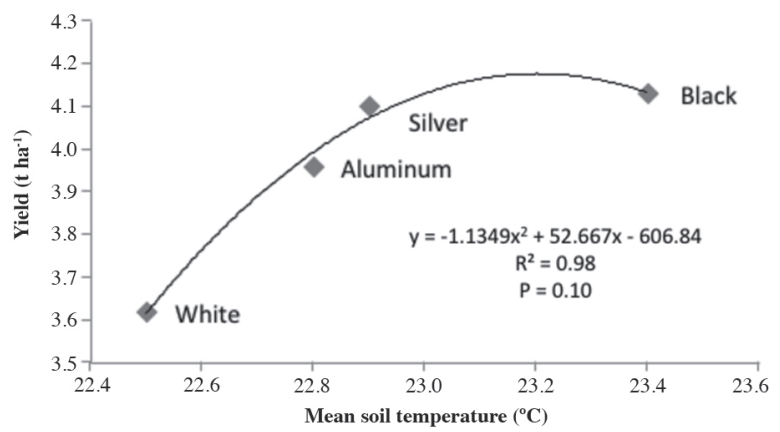

Figure 5. Relationship between mean soil temperature and yield of dry beans cultured with differentially colored plastic mulches in the first of two growing seasons. but according to previous experiments dry bean yield is susceptible to seeding dates and can decay as spring advances (Ibarra Jiménez and Rodríguez Piña, 1997). The use of temperatures generated by different mulch colors allows a better comprehension of the response of dry bean plants to double cropping.

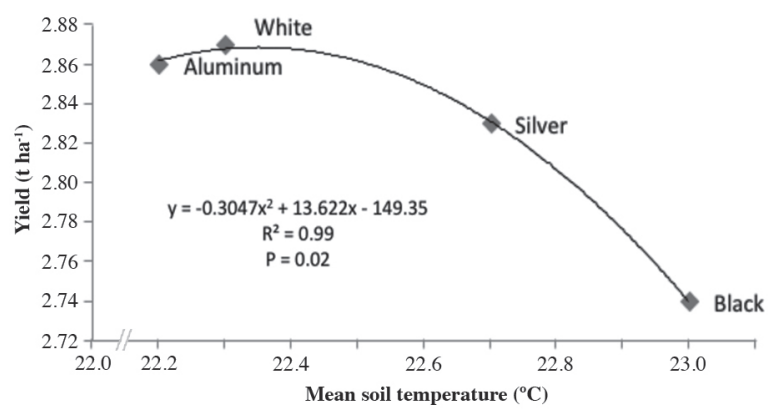

Figure 6. Relationship between mean soil temperature and yield of dry beans cultured with differentially colored plastic mulches in the second of two growing seasons.

\section{CONCLUSIONS}

Our findings support the premise that it is possible to obtain two growing seasons of dry bean in the same plastic mulched soil. The yield of dry bean crops responded favorably to early seeding dates using new plastic mulch in the first crop. The same response was not observed in late dates with plastic mulch used in the second crop. The mean soil temperature correlated with yield, but higher soil temperatures induced by plastic mulch were not the only the factor explaining higher yields, which was particularly true in the second crop.

Influencia del doble cultivo en el crecimiento y rendimiento de frijol con cubierta plástica de colores. Existen numerosos estudios sobre el uso de cubierta plástica en la producción de hortalizas, sin embargo está muy poco documentado el cultivo simple o doble de frijol (Phaseolus vulgaris L.). El objetivo de este estudio fue cultivar frijol en dos estaciones de crecimiento consecutivas usando la misma cubierta plástica de diferentes colores y examinar la influencia de la temperatura del suelo en el crecimiento y rendimiento de frijol. El estudio fue conducido en Saltillo, Coahuila, México, en la primavera y verano de 2008. Se usaron cuatro colores de acolchado plástico: blanco-sobrenegro, negro, plata-sobre-negro, aluminio-sobre-negro, y control de suelo desnudo. El diseño experimental fue bloques completos al azar con cuatro repeticiones. El porcentaje de radiación fotosintéticamente activa (PAR) reflejada por las cubiertas tendió a ser mayor en el plástico blanco-sobre-negro y menor en cubierta negra. La temperatura media bajo la cubierta decreció con el incremento en el porcentaje de PAR reflejada. La temperatura media del suelo se relacionó con rendimiento 
en $98 \%$ y $99 \%$ en la primera y segunda estación de crecimiento, respectivamente. La relación entre PAR y rendimiento fue $98 \%$ y $86 \%$ en la primera y segunda estación de crecimiento, respectivamente. El efecto de la cubierta de color sobre el rendimiento fue significativo ( $p$ $\leq 0,05$ ) en la primera estación de crecimiento, pero no en el segundo cultivo donde los tratamientos de cubierta y el control tuvieron un rendimiento similar, indicando que no siempre la cubierta aumenta el rendimiento.

Palabras clave: Phaseolus vulgaris, temperatura del suelo, fotosíntesis, radiación fotosintéticamente activa, plasticultura.

\section{LITERATURE CITED}

Antonious, G.F., and M.J. Kasperbauer. 2002. Color of light reflected to leaves modifies nutrient content of carrot roots. Crop Science 42:1211-1216.

Csizinszky, A.A., D.J. Schuster, and J.B. Kring. 1995. Color mulches influence yield and insect pest populations in tomatoes. Journal of the American Society for Horticultural Science 120:778-784.

Decoteau, D.R. 2007. Leaf area distribution of tomato plants as influenced by polyethylene mulch surface color. HortTechnology 17:341-345

Díaz-Pérez, J.C. 2009. Root zone temperature, plant growth and yield of broccoli [Brassica oleracea (Plenck) var. italica] as affected by plastic film mulches. Scientia Horticulturae 123:156-163.

Díaz-Pérez, J.C. 2010. Bell pepper (Capsicum annum L.) grown on plastic film mulches: Effects on crop microenvironment, physiological attributes, and fruit yield. HortScience 45:11961204.

Díaz-Pérez, J.C., and K.D. Batal. 2002. Colored plastic film mulches affect tomato growth and yield via changes in root-zone temperature. Journal of the American Society for Horticultural Science 127:127-135.

FAO. 2010. Misión FAO/PMA de evaluación de cosecha y seguridad alimentaria en Guatemala. Organización de las Naciones Unidas para la Agricultura y la Alimentación. Programa Mundial de Alimentos (PMA). Available at http://issuu.com/maijala/docs/ srguatemala0210 (accessed December 2011).
Ham, J.M., G.J. Kluitenberg, and W.J. Lamont. 1993. Optical properties of plastic mulches affect the field temperature regime. Journal of the American Society for Horticultural Science 118:188-199.

Hanna, H.Y. 2000a. Black polyethylene mulch does not reduce yield of cucumbers double-cropped with tomatoes under heat stress. HortScience 35:190-191.

Hanna, H.Y. 2000b. Double-cropping muskmelons with nematoderesistant tomatoes increases yield, but mulch color has no effect. HortScience 35:1213-1214.

Ibarra-Jiménez, L., R.H. Lira-Saldivar, L.A. Valdez-Aguilar, and J. Lozano-Del Río. 2011. Colored plastic mulches affect soil temperature and tuber production of potato. Acta Agriculturae Scandinavica Section B, Soil and Plant Science 61:365-371.

Ibarra Jiménez, L., y A. Rodríguez Piña. 1997. Acolchado de suelos con películas plásticas. 132 p. Editorial Limusa, D.F. México.

Kasperbauer, M.J. 2000. Strawberry yield over red versus black plastic mulch. Crop Science 40:171-174.

Kasperbauer, M.J., J.H. Loughrin, and S.Y. Wang. 2001. Light reflected from red mulch to ripening strawberries affects aroma, sugar and organic acid concentrations. Photochemistry and Photobiology 74:103-107.

Lamont, J.W. 2005. Plastics: Modifying the microclimate for the production of vegetable crops. HortTechnology 15:477-481.

Mayfield, J.L., E.H. Simone, Ch.C. Mitchel, J.L. Sibley, R.T. Boozer, and E.L. Vinson III. 2002. Effect of current fertilization status of double-cropped tomato and cucumber produced with plasticulture. Journal of Plant Nutrition 25:1-15.

Ngouajio, M., and J. Ernest. 2005. Changes in the physical, optical, and thermal properties of polyethylene mulches during double cropping. HortScience 40:94-97.

SAS Institute. 2009. PROC GLM. Windows Version 9. SAS Institute, Cary, North Carolina, USA.

Summers, C.G., J.J. Stapleton, A.S. Newton, R.A. Duncan, and D. Hart. 1995. Comparison of sprayable and film mulches in delaying the onset of aphid - borne virus diseases in zucchini squash. Plant Disease 79:1126-1131.

Waterer, D., W. Hrycan, and T. Simms. 2007. Potential to doublecrop plastic mulch. Canadian Journal of Plant Science 88:187193. 